\title{
DISCOVERY IN PATENT INTERFERENCES- LEGISLATION BY COURTS AND CONGRESS
}

The statutory provision governing discovery in patent interferences ${ }^{1}$ has been in its present form for almost a quarter of a century, ${ }^{2}$ but only since 1968 have the federal courts of appeals recognized that the measure is open to differing imterpretations. ${ }^{3}$ On its face, section 24 of the Patent Act of 1952 seems to incorporate the full panoply of broad discovery permitted by the Federal Rules of Civil Procedure into inter partes litigation before the Patent Office. This was the view adopted by the Third Circuit in $1968 ; ;^{4}$ recently, however, the Third Circuit, ${ }^{5}$ followed by the First Circuit, ${ }^{b}$ lias concluded, in light of the unique policies underlying an interference, that Congress could not liave intended to expand the scope of discovery beyond the strictly limited provisions which were in effect prior to 1952 .

To perceive the precise nature of the controversy involved, it is necessary to understand how an interference proceeding is conducted. ${ }^{7}$ The proceeding itself is a "quasi-judicial . . . proceeding instituted by the . . . Patent Office to determine the priority of invention between rival claimants of the same patentable subject matter." ${ }^{\prime \prime}$ The applicant who is first in time is called the senior party and the other is designated the junior party. The order in which the parties are arranged is of great importance because the senior party is presumed to have made the invention. ${ }^{9}$ Eacli party to an interference must first file a sworn preliminary statement giving certain facts and dates pertaining to his invention. The statenent is, in effect, a pleading and tradition-

THE FOLLOWING CITATION WILL BE USED IN THIS NOTE:

C. Rrvise \& A. Caesar, Interference LaW and Practice (1940) (hereinafter cited as RIVISE \& CAESAR).

1. 35 U.S.C. $\$ 24$ (1970).

2. Act of July 19,1952 , ch. $2, \S 24,66$ Stat. 795 (codified at 35 U.S.C. $\S 24$ (1970)).

3. See In re Natta, 388 F.2d 215, 156 U.S.P.Q. 289 (3d Cir. 1968).

4. Id.

5. Frilette v. Kimberlin, 508 F.2d 205, 184 U.S.P.Q. 266 (3d Cir. 1974), cert. denied, 43 U.S.L.W. 3614 (U.S. May 20, 1975).

6. Sheehan v. Doyle, Civil No. 74-1318 (1st Cir. Mar. 31, 1975). After this Note went to press, Sheehan was reported at 513 F.2d 895 (1st Cir. 1975), and petition for certiorari filed, 44 U.S.L.W. 3001 (U.S. June 27, 1975) (No. 74-1644).

7. For general discussion of the procedure, see the authorities cited in note $30 \mathrm{in}$ fra.

8. Epperson, Interferences, in The Encyclopedia of Patent Practice and INvention MaNagement 467 (R. Calvert ed. 1964).

9. See A. Seidel, What the General Practitioner Should Know About PatENT LAW AND PRACTICE 66 (1966). 
ally has been filed without knowledge of the dates alleged by the other parties. After the statements have been filed the Examiner of Interferences sets a time limit ${ }^{10}$ within which the parties may file any motions specified in Patent Rules 232 to $235,{ }^{11}$ or deemed appropriate pursuant to Patent Rule 243. ${ }^{12}$ If the interference survives this motion period, the "trial" begins. The Examiner of Interferences starts the trial by sending notices to the parties in which they are assigned time periods for the taking of the testimony-in-chief, and the jumior party, who is required to produce his evidence first, is assigned a further time within which he may take rebuttal testimony. ${ }^{13}$ Unless there is specific agreement by the parties to the contrary, ${ }^{14}$ the testimony is taken only by depositions after notice to the opposing party, and with opportunity for him to cross-examine. ${ }^{15}$ Evidence which has not been taken and filed in compliance with the patent rules ${ }^{16}$ and the rules of evidence ${ }^{17}$ will not be considered. Briefs and reply briefs are then filed with the Board of Patent Interferences and oral argument is given before a panel of the Board, ${ }^{18}$ followed by a decision. The trial of an interference, then, consists of the taking of evidenee prior to the hearing. Events prior to the taking of evidence are but preliminaries, and events subsequent are nothing more than the presentation of proposed findings of facts by the parties, supported by references to, and analysis of, previously collected evidence.

Section 24 of the Patent Act of $1952^{19}$ gives any federal district court in the jurisdietion where testimony is to be taken for use in a patent interference the power to compel the attendance of a witness and the production of "documents and things" in his possession. The statutory language in issue--discussing when a party can begin an ancillary proceeding in the district court in order to compel discovery and the scope of discovery permissible in such a proceedimg - reads: "The provisions of the Federal Rules of Civil Procedure relating to the attendance of witnesses and to the production of documents and things shall apply to contested cases in the Patent Office." ${ }^{20}$ In spite of

10. Patent Rule 231, 37 C.F.R. $\$ 1.231$ (1974).

11. Id. $\S \S 1.231(\mathrm{a})(1)-(5)$.

12. Id. $\S 1.243$.

13. Id. $\& 1.251$. See authorities cited in note 30 infra.

14. The statutory provision allows the presentation of trial evidence by affidavit or stipulation if the parties agree. Id. $\$ 1.272$.

15. Id. § 1.273 .

16. Id. $\$ 1.271$.

17. Id. $\S 1.286$.

18. Id. $\S \S 1.254 .256$.

19. 35 U.S.C. $\S 24(1970)$.

20. Id. Both patent grants and trademark registrations are handled by the United 
the apparent clarity and simplicity with whicl section 24 is stated, ${ }^{21}$ the courts have not agreed in their construction of the measure. Most lave held that the statute should be given a literal reading, i.e., broad discovery at all stages of the proceeding. ${ }^{22}$ Two courts, however, have recently maintained that section 24 reveals no congressional intent to enlarge the statutory power of the district courts to compel discovery. ${ }^{23}$ Rather, the statute is viewed as merely continuing essentially the same power formerly given the courts under the statutory antecedent of section 24. ${ }^{24}$ What the latter proposition ineans in practical terms is that there could be no discovery of adverse information to prepare the parties fully for what might be produced by their opponents. $^{25}$ Instead, all a court could compel is production of evidence

States Patent Office, the latter also precipitating inter partes litigation and thus subject to section 24. Trademark texts and cases prior to July 1, 1972, are therefore pertinent. On that date, however, the discovery provisions of the Federal Rules of Civil Procedure became applicable to trademark cases. Rule 2.120, 37 C.F.R. $\$ 2.120$ (1974). With exceptions irrelevant to this inquiry, section 24 was thus relegated to a non-discovery function. See generally $1 \mathrm{~J}$. McCarthy, Trademarks and UNFaIR Competition $\$ \$ 6: 3$, 20:29 (1973); E. VandenbuRgh, Trademark LaW and Procedure $\S \S 10.30-.40$ (2d ed. 1968).

21. The Supreme Court has insisted that the plain or ordinary meaning of words used in a statute is to govern its construction: "We are not at liberty to construe language so plain as to need no construction, or to refer to Committee reports where there can be no doubt of the meaning of the words used." Helvering v. City Bank Farmers Trust Co., 296 U.S. 85, 89 (1935) (footnotes omitted). See Banks v. Chicago Grain Trimmers Ass'n, 390 U.S. 459, 465 (1968); Malat v. Riddle, 383 U.S. 569, 571 (1966). But see Texas \& Pac. Ry. v. Abilene Cotton Oil Co., 204 U.S. 426 (1907), where the Court ignored unambiguous statutory language and interpreted the governing legislation as having a meaning diametrically opposed to the clear import of the language.

22. See notes 85-88 infra and accompanying text.

23. Frilette v. Kimberlin, 508 F.2d 205, 184 U.S.P.Q. 266 (3d Cir. 1974), cert. denied, 43 U.S.L.W. 3614 (U.S. May 20, 1975); Sheehan v. Doyle, Civil No. 74-1318 (1st . Cir., March 31, 1975).

24. The predecessor of section 24 was section 7 of the 1922 Patent Act. Act of Feb. 18, 1922, ch. 58, $\$ 7,42$ Stat. 391. It provided for the issuance of a subpoena duces tecum only where a right to the now antiquated deposition dedimus potestatem existed, which itself was conditioned on the satisfaction of numerous restrictive requirements. See generally 4 J. MoORe, Federal Practice IT 26-77 to -78 (1974).

In addition to this sizeable restriction on the scope of discovery, the statutory antecedent of section 24 made clear that the policy underlying discovery was the securing of admissible evidence pertaining only to the discoverer's own case, not that of his adversary, and the courts employed this policy to further narrow the range of discovery. See, e.g., Tucker v. Peiler, 297 F. 570 (2d Cir.), cert. denied, 265 U.S. 581 (1924); Umited States v. Terminal Ry. Ass'n, 154 F. 268 (8th Cir. 1907); Schuricht v. McNutt v. Willis, 26 F.2d 388 (D. Conn. 1928).

Discovery, however, is available to a limited extent pursuant to Patent Rule 287. See note 124 infra and accompanying text.

25. As used in this Note, the term "discovery" will refer to the broad discovery mandated by the Federal Rules of Civil Procedure and limited only by considerations of relevancy. This should be contrasted with the more limited Patent Office discovery which is governed by standards of admissibility at trial. 
which would be admissible to prove part of the discoverer's claim or defense. ${ }^{26}$ Since evidence must be procured at the trial stage of the proceeding to be admissible, ${ }^{27}$ all pretrial discovery is necessarily precluded.

These contrasting interpretations of the statute take on great significance when examined in the context of the theory and practice of the patent interference and, perhaps not surprisingly, policy considerations have colored the inanner in which courts view the congressional intent inanifested in section 24.

A recent decision by the Court of Appeals for the Third Circuit, ${ }^{28}$ expressly overruling its construction of the Patent Act only six years before, ${ }^{20}$ emphasizes one conflict between the policies underlying the federal discovery rules and the structure of the interference proceeding. The aim of the rules is free accessibility of information for the litigants in any civil trial, where there is generally no policy reason to treat any party differently from another. A patent interference, on the other hand, is instituted solely to determine which of two or more parties claiming the right to a patent is the prior inventor. ${ }^{30}$ Presumably to encourage early filing of patent applications, ${ }^{31}$ the interference proceeding is designed to give a "substantial advantage"32 to the party which filed its patent application first. The American system is "virtually unique" in permitting the later applicant to challenge at all: "in most countries the first inventor to file in the Patent Office is conclusively presumed to be the prior inventor."33 But, while a later

26. There was one exception to the Pateut Office rule that all documents sought for production must be admissible evidence. Under the predecessor of Patent Rule 273, 37 C.F.R. \& 1.273 (1974), the opposing party had full opportunity to cross-examine the deponents. Pursuant to that rule the courts, even prior to the federal rules, made an exception to the federal practice concerning discovery. The taking of depositions was viewed as a trial, and it was held to be within the discretion of the court to deny a subpoena for the production of documents when it appeared that the documents were not for use as evidence, but for use of counsel in cross-examining a witness. See, e.g., Tueker v. Peiler, 297 F. 570 (2d Cir.), cert. denied, 265 U.S. 581 (1924).

27. Patent Rule 271, 37 C.F.R. \$ 1.271 (1974).

28. Frilette v. Kimberlin, 508 F.2d 205, 184 U.S.P.Q. 266 (3d Cir. 1974), cert. denied, 43 U.S.L.W. 3614 (U.S. May 20, 1975).

29. In re Natta, 388 F.2d 215, 156 U.S.P.Q. 289 (3d Cir. 1968).

30. 35 U.S.C. $\$ 135$ (1970). See generally 1 RIviSe \& CAESAR \$ 1; A. SEIDEL, supra note 9, at 66-72; Baker, Outline of Patent Office Interference Practice (pts. 1-3), 36 J. PAT. OFF. Soc'y 30, 33 (1954); Epperson, supra note 8.

31. Cf. Ecaubert v. Hofman, 1890 Dec. Com. Pat. 143, 145, where the Commissioner of Patents reiterated his view that the burden of proof advantage accorded the first filer rests on the legal maxim prior tempari potior jure ("He who is first in time is first in right"). See generally 3 RIVISE \& CAESAR $\$ 405$.

32. Epperson, supra note 8, at 4.70.

33. See 2 J. Baxter, World Patent Law and Practice 184 (1975); A. Semel, supra note 9, at 66 . 
American applicant may challenge to show that he is in fact the "first inventor,"34 he must not only bear the burden of proof ${ }^{35}$ but must also present all his evidence first. ${ }^{36}$ The broad discovery provisions of the federal rules would undercut this "order of precedence"37 by giving the later party an opportunity to adjust his submission of evidence to take into account the information he has been able to gather before or during his own presentation.

A second source of tension stems from the crucial role played by the alleged imvention dates in the patent interference. ${ }^{38}$ The Patent Office has long considered the possibility of fraud or perjury in an interference proceeding paramount, ${ }^{39}$ because the sole object of the proceeding is to determine priority of invention and because the allegation of an invention date is susceptible to manipulation. Reflecting this peculiar concern are Patent Office practices barring a party from proving an invention date earlier than that alleged in the preliminary statement ${ }^{40}$ and tightly restricting the amendment of dates. ${ }^{41}$ Parties have traditionally been required to file preliminary statements in ignorance of the allegations of their adversaries, as the Patent Office seeks an "honest statement of the essential facts and dates ...."42 The impact of broad discovery, especially at the pretrial stage, on this procedural protection is obvious; the Patent Office policy of secrecy would be effectively eradicated. While the fear of fraud or perjury also underlies the pre-rules posture of narrow discovery, ${ }^{43}$ the Patent Office has viewed the problem as peculiarly significant in the interference context and has advocated secrecy at the preliminary statement stage for at least 100 years in an effort "to obviate the interminable wrangling and the induceinents to perjury that exist . . . ."44

Still another problein area is the potential administrative burden resulting from the grafting of broad discovery onto a procedural structure not designed to accommodate it. In patent proceedings the right

34. 2 J. BAXTER, supra note 33 , at 184.

35. See 3 RIVISE \& Caesar $\$ 405$; A. Semer, supra note 9, at 66.

36. See notes $37-44$ infra and accompanying text.

37. Frilette v. Kimberlin, 508 F.2d 205, 210, 184 U.S.P.Q. 266, 269 (3d Cir. 1974), cert. denied, 43 U.S.L.W. 3614 (U.S. May 20, 1975).

38. See 2 J. BAXTER, supra note 33, at 189; A. SEIDEL, supra note 9, at 68-70.

39. See Woodward v. Kennedy, 1903 Dec. Com. Pat. 166, 104 O.G. Pat. Off. 1393; Clark v. Brooks, 1874 Dec. Com. Pat. 84, 6 O.G. Pat. Off. 296. See also 1 RIvise \& Caesar $\$ 86$.

40. Patent Rule 223, 37 C.F.R. § 1.223 (1974).

41. See note 63 infra.

42. 1 RIVISE \& CAESAR $\$ 86$, at 246.

43. See note 74 infra.

44. Clark v. Brooks, 1874 Dec. Com. Pat. 84, 6 O.G. Pat. Off. 296. 
to collect evidence has traditionally hinged on the right to use it, ${ }^{45}$ a practice still contemplated by the patent rules. ${ }^{40}$ Discovery then is a function of the admissibility of the information sought. The broad discovery under the rules, not limited by technical requirements of admissibility, could precipitate numerous objections at the trial stage of a proceeding. For fear of waiving his objection on grounds of admissibility, ${ }^{47}$ a party may be forced to object to requests for inadmissible evidence even though the discovering party intends to use the information solely as a means of pursuing admissible material. Conversely, the discovering party is under pressure to file all discovered material in the record, ${ }^{48}$ in spite of its clear inadmissibility. Unlike the friction between broad discovery and Patent Office policies favoring the first to file and maintaining secrecy of imvention dates, however, this administrative problein can be cured without seriously damaging a policy espoused by the Patent Office. There is no apparent reason why the rules governing the conduct of an interference could not be altered to accommodate broad discovery while still limiting the record itself to admissible material. This administrative burden is thus not as important as the policy conflicts discussed above.

When Congress incorporated discovery provisions into the patent interference, it could have adopted either of two approaches. On the one hand, Congress could have preferred the policy of the federal rules, making broad discovery available during one or both stages of the interference. Alternatively, the legislature imght have tailored the scope of discovery in patent interferences to something less than access to all possibly relevant material, concluding that a less pervasive use of discovery is more suitable for the interference than that einployed in ordinary civil actions. This Note will explore the question of which alternative Congress actually chose when it adopted section 24 by examining the legislative history and the case law and discussing the policy implications of possible interpretations of the statutory language.

\section{Legislative History of Section 24}

It can be argued that the legislative history of section 24 manifests a legislative intent merely to maintain for federal district courts the same limited powers to compel discovery which they possessed

45. See note 24 supra.

46. See 37 C.F.R. $\S \S 1.272,1.278,1.285-86$ (1974). But see id. $\S 1.287$ (new Patent Office discovery provision). See also note 124 infra.

47. Patent Rule 285(c) provides that objections to the admissibility of deposition testimony are not waived "unless the grant of the objection is one which might have been obviated or removed if presented at that time." Id. $\$ 1.285(\mathrm{c})$.

48. See Patent Rule 278, id. $\$ 1.278$. 
prior to the advent of the federal rules. ${ }^{49}$ The committee reports of both the Senate and the House state in part:

Although the principal purpose of the bill is the codification of Title 35 United States Code, and involves simplification and clarification of language and arrangement, and elimination of obsolete and redundant provisions, there are a number of changes in substantive statutory law. These will be explamed in some detail in the revision notes keyed to each section which appear in the appendix of this report.50

The appendices of the reports referring to section 24 provide:

Three sections of the existing statute are combined with some changes in language and placed in part 1 since they apply to trade-mark cases in the Patent Office as well as to patent cases. Reference to a repealed statute in the first paragraph is replaced by reference to the Federal Rules of Civil Procedure and certain rules are made applicable. ${ }^{51}$

Froin these excerpts it could be concluded that, since a change which would incorporate broad discovery into patent interferences is obviously "substantive," and since the committees had made no note of any substantive change in enacting section 24 , neither they nor the Congress could have intended any such change. ${ }^{52}$

There are, however, a host of problems with this analysis. First, there is some evidence that Congress considered drafting section 24 to effect narrower ends but decided not to do so. ${ }^{53}$ Second, the preceding statute provided only for the issuance of subpoenas, ${ }^{54}$ now governed solely by rule 45 , while the statute and committee reports were framed in plural terms, apparently referring to incorporation of more than one rule. ${ }^{55}$ The law, then, has been modified ${ }^{56}$ at least as to the meth-

49. See Frilette v. Kimberlin, 508 F.2d 205, 184 U.S.P.Q. 266 (3d Cir. 1974), cert. denied, 43 U.S.L.W. 3614 (U.S. May 20, 1975).

50. S. REP. No. 1979, 82 d Cong., 2d Sess. 4 (1952); H.R. REP. No. 1923, 82d Cong., 2d Sess. 5 (1952).

51. S. Rep. No. 1979, 82d Cong., $2 d$ Sess. 4 (1952); H.R. REP. No. 1923, 82d Cong., 2d Sess. 5 (1952).

52. In re Natta, 388 F.2d 215, 221-22, 156 U.S.P.Q. 289, 294 (3d Cir. 1968) (dissenting opinion); see Frilette v. Kimberlin, 508 F.2d 205, 212 n.15, 184 U.S.P.Q. 266, 271 n.15 (3d Cir. 1974), cert denied, 43 U.S.L.W. 3614 (U.S. May 20, 1975); Comment, Discovery Provisions of the Federal Rules of Civil Procedure as Applied to Patent Interference Proceedings, 73 Dick. L. REv. 509 (1969).

53. H.R. 3760 which became the Patent Act of July 19, 1952, ch. 1 et seq., 66 Stat. 792, was actually a revision of an earlier model, H.R. 9133, which recited in part: “. . . and the provisions of the Federal Rules of Civil Procedure relating to the issuance of subpoena duces tecum shall apply to contested cases in the Patent Office." See 508 F.2d at 213-14 (dissenting opinion).

54. See note 24 supra.

55. See In re Natta, 388 F.2d 215, 217, 156 U.S.P.Q. 289, 290-91 (3d Cir. 1968). See also note 51 supra and accompanying text.

56. Frilette v. Kimberlin, 508 F.2d 205, 213, 184 U.S.P.Q. 266, 271 (3d Cir. 1974), cert. denied, 43 U.S.L.W. 3614 (U.S. May 20, 1975) (dissenting opinion). 
ods of discovery available in the patent interference, if not with regard to the scope of discovery available through any given procedure.

Furthermore, there is at least one "substantive change" from prior law: ${ }^{57}$ abandonment of the limitation that a subpoena duces tecum be issued only when there is a concurrent right to a specific type of deposition which itself was conditioned upon the satisfiction of numerous requirements. ${ }^{58}$ The rules pertaining to "the attendance of witnesses and the production of documents and things," noreover, need no explanation in and of themselves. Since the language of section 24 creates no ambiguity if read hterally, the committees arguably concluded that no explanation of the change was necessary. A final flaw in the analysis stems from the clarity of the language of section 24 . Had the provision been intended to perpetuate the former limited discovery procedure, the statute is very poorly worded for this purpose. The absence of the word "discovery" in the measure is hardly compelling, ${ }^{59}$ when one considers that the Rules relating to "attendance of witnesses and the production of documents and things" are discovery rules. ${ }^{60}$

In short, it is unlikely that Congress intended only to restate prior law when it enacted section 24. True, there were no revision notes, which were promised in the event of a change in substantive law; however, the conclusion is unavoidable that the law was altered at least with respect to the modes of discovery available and the accompanying conditions. Once that is recognized, it becomes difficult to mamtain that the absence of revision notes indicates that Congress did

57. By adopting the position that the scope of discovery is now governed solely by certain sections of rule 45 , the Frilette court apparently has discarded the former requirement for a deposition dedimus potestatem as an independent requirement for the issuance of a subpoena duces tecum. Frilette v. Kimberlin, 508 F.2d 205, 212, 184 U.S.P.Q. 266, 270 (3d Cir. 1974.), cert. denied, 43 U.S.L.W. 3614 (U.S. May 20, 1975). See note 24 supra.

58. See generally 4 J. MoORE, supra note 24 , fit 26-77 to -78 .

59. There is some merit in the contention of the Frilette court that Congress would have employed the word "discovery" had it meant to effect a substantive change from prior interference practice. 508 F.2d at 211,184 U.S.P.Q. at 270 . The language of bills introduced in both the House and the Senate during the last term supports the view. "[T]he provisions of the Federal Rules of Civil Procedure relating to the attendance of witnesses, discovery, and the production of documents and things shall apply." S. 2930, 93d Cong., 2d Sess. $\$ 24$ (1974); H.R. 11,868, 93d Cong., 1st Sess. (1973) (einphasis added).

60. Perhaps the better argument is that advanced by the First Circuit in Sheehan v. Doyle, Civil No. 74-1318 (1st Cir. March 31, 1975). The court attached greater importance to what the statute and legislative history left unsaid than to its express provisions. "If Congress had intended to erect a freewheeling discovery vehicle totally outside the control of the Patent Office, one would have expected some inkling in the legislative history." $l d$. at 6 . 
statements clearly would eliminate this built-in procedural protection, it might reasonably be maintained that Congress did not intend section 24 to authorize pretrial discovery at all. Alternatively, the statute might be interpreted to encompass pretrial discovery only after filing of preliminary statements. The problem with the latter approach is its inconsistency with procedure under the federal rules. Interferences are commenced by the Examiner when he provides notice to the involved parties. ${ }^{64}$ Simce the federal rules make it clear that discovery can proceed unhampered from the commencement ${ }^{65}$ of the action, ${ }^{63}$ discovery would be available prior to the filing of preliminary statements.

The second option is to limit discovery to the trial stage of the proceedings. That would mean retaining the prior practice of not allowing any discovery at or before the point when preliminary statements are presented or notions filed. ${ }^{67}$ Yet, broad discovery solely at the trial stage of the proceeding poses its own peculiar problems in the form of burdening the administrative process. ${ }^{68}$ Evidence procured must still be filed in the Patent Office ${ }^{09}$ and objected to in timely fashion, ${ }^{70}$ since the present patent rules contemplate that all evidence gathered during the trial stage is being collected as part of the record, not merely to lead to other evidence meant to becoine part of the record. ${ }^{71}$

The third option, that broad discovery is available at both

ing that it is based on newly discovered evidence which could not have been discovered despite diligent preparation in making the original statement. Methudy v. Roy, 65 F.2d $171,173,17$ U.S.P.Q. 505, 508 (C.C.P.A. 1933). Just as significantly, in those situations where a party was allowed to amend his preliminary stateinent after he had learned of the dates alleged by his opponent, the courts and Patent Office tribunals have put a greater burden of proof upon the amending party because of the suspicion cast upon him. See, e.g., Duemler v. McCabe, 67 F.2d 911, 914 (C.C.P.A. 1933). In short the policy is clear that "[i]n the very nature of things, the prosecution of patent applications up to a certain point must be in secret." Methudy v. Roy, 65 F.2d 171, 174, 17 U.S.P.Q. 505, 508 (C.C.P.A. 1933).

64. 1 RIVISE \& CAESAR at 6.

65. Rule 3 of the federal rules provides "a civil action is commenced by filing a complaint with the court." Fed. R. CIV. P. 3.

66. 4A J. MOORE, supra note $24, \pi 34.06$.

67. The right to collect evidence and the right to use it were not kept distinct under prior practice. See note 24 supra. As a result, discovery at these pretrial stages of the proceeding, encumbered with rules as to admissibility, was not allowed because of the patent practice of permitting into the record only evidence procured at trial. See notes 13-17 supra and accompanying text.

68. See notes $45-48$ supra and accompanying text.

69. Patent Rule 278, 37 C.F.R. $\$ 1.278$ (1974) (which provides for the filing of depositions which, under Rule 277, id. \$1.277, include exhibits).

70. Patent Rule 285(c), id. $\$ 1.285(\mathrm{c})$.

71. Patent Rule 286, id. § 1.286 . 
not intend to replace the prevailing narrow scope of discovery with a broader rule. ${ }^{01}$ Rather, the absence of revision notes should be interpreted as reflecting congressional belief that the changes merited no extended discussion. The statutory language is so explicit in its mandate of change, and Congress has demonstrated such a sufficient understanding of the alternatives open to it by rejecting proposed legislation, that there is every reason to beheve the changes were intentional.

\section{CONFLicting INTERPRETATIONS OF THE SCOPE OF SECTION 24}

After one accepts the proposition that broad discovery was intended to apply in patent interferences, it is still necessary to determine at which stage of the proceedings the parties may resort to the ancillary jurisdiction of federal district courts to seek discovery. The three options are: (1) discovery only at the pretrial stage-that is, prior to the actual taking of evidence which will constitute the record; (2) discovery at the "trial" stage-that is, during the taking of evidence; or (3) discovery at both stages.

If broad discovery is to be allowed during the pretrial stage of the interference, Patent Office policy could be significantly impaired. The problem stems from the fact that the proceeding is officially initiated when the notice of interference is mailed to each of the parties, ${ }^{62}$ who then respond by filing a preliminary statement. The Patent Office has, however, sought at this early stage to minimize the opportunity for fraud and perjury in stating the crucial dates by forcing the parties to file without being advised of the contentions of their opponents. ${ }^{03}$ Because broad discovery prior to the filing of the preliminary

61. But see Prilette v. Kimberlin, 508 F.2d 205, 184 U.S.P.Q. 266 (3d Cir. 1974), cert. denied, 43 U.S.L.W. 3614 (U.S. May 20, 1975); In re Natta, 388 F.2d 215, 221-23, 156 U.S.P.Q. 289, 294-95 (3d Cir. 1968) (dissenting opinion); Comment, supra note 52.

62. See text accompanying notes 18-23 supra.

63. Patent Rule 226, 37 C.F.R. $\$ 1.226$ (1974), stipulates that the Examiner of Interferences is not to provide any party with the serial number and filing date of any adverse party or with notice of any applications in addition to those directly involved in the interference (which the parties are otherwise entitled to inspect) until after the preliminary statements lave been filed and approved or the time for filing has expired. This takes on extreme importance because of the significance of the preliminary stateinents. Patent Rule 223(b), id. $\$ 1.223$, states that "[i] $f$ a party proves any date earlier than alleged in lis preliminary statement, such proof will be held to establish the date so alleged and none earlier." Rule 223(a), id. \$ 1.223(a), warns applicants to prepare their preliminary statements carefully, while Rule 222, id. $\$ 1.222$, makes it clear that the Commission frowns on any attempts to annend them. Anendment requires a "satisfactory showing that [the correction] is essential to the ends of justice." Iu circumstances where an amendment is attempted after the other party's dates are known from inspections of his statement, the applicant's notion to amend must be accompanied by a slow- 
stages of the interference, appears to be the most logical. The statute includes no explicit limitations on when discovery may take place. It is thus inconsistent to contend that section 24 should be literally construed with respect to what can be discovered, while finding implied limitations on the timing of discovery. Fimally, applicable to all three options is the objection that discovery requiring a semior party to provide information to a junior party at any stage prior to completion of the junior party's testimony-in-chief would frustrate the Patent Office's procedural preference for the semior party. ${ }^{72}$

The recently voiced argument that section 24 does not mandate wide-ranging discovery at any stage of the interference ${ }^{73}$ forms the basis for still another interpretation of the statute. The effect of the federal rules was to eliminate restrictions ${ }^{74}$ upon discovery, a policy founded on the notion that parties should have access to all relevant information. The restrictions on discovery in patent interferences, lowever, rest on additional policy foundations, namely the need for secrecy with regard to the crucial allegations of dates at the preliminary statement stage and the need to protect the procedural advantage accorded the senior party. Thus, while the federal rules served to remove the overlay of discovery restrictions in civil actions generally, it does not follow automatically that the same restrictions in patent interferences-there because of the peculiar structure of the proceeding itself_-must similarly be removed.

There are two problems with this view. First, section 24 does not speak of incorporating the policy behind the federal discovery rules, but rather the provisions of the rules themselves. Obviously there is a danger of fraud or perjury if discovery is allowed prior to the filing of the preliminary statements, but that same fear was expressed about pretrial discovery in general earlier in the nineteenth century. ${ }^{75}$ If a court, after enactinent of the federal rules, had concluded that

72. See notes 30-33 supra and accompanying text.

73. Frilette v. Kimberlin, 508 F.2d 205, 184 U.S.P.Q. 266 (3d Cir. 1974), cert. denied, 43 U.S.L.W. 3614 (U.S. May 20, 1975); Sheehan v. Doyle, Civil No. 74-1318 (1st Cir., March 31, 1975). See also In re Natta, 388 F.2d 215, 221-23, 156 U.S.P.Q. 289, 293-95 (3d Cir. 1968) (dissenting opinion); Comment, supra note 52.

74. The rationale behind restrictions on discovery was summarized early in the nineteenth century:

Experience : . has shown-or, at least, courts of justice in this country act upon the principle-that the possible mischiefs of surprise at a trial are more than counterbalanced by the danger of perjury which must inevitably be incurred when either party is permitted before a trial to know the precise evidence against which he has to contend. J. Wigram, PoINTS IN THE LAW OF DISCOVERY § 148 (1836).

75. See id. 
there was still a problem as to perjury, surely no one would suggest that it could have altered the application of the rules.

The second problem hes in the fact that the statute pertains not only to patent contests but also to trademark litigation. ${ }^{76}$ The issues raised in trademark contests do not as a rule require the pretrial secrecy or order of precedence between parties of a patent interference. For instance, the issue may be whether the trademark in dispute so closely resembles a previously registered trademark as to cause confusion to the public. ${ }^{77}$

Thus, it does not appear that Congress gave any weight to the unique nature of patent interference proceedings when it promulgated section 24. The niere existence of such special attributes, then, should not be the governing factor in construing the statutory provision.

\section{Judicial Response to Section 24}

Prior to 1968 , the courts did not squarely address the issue of the scope of discovery under section 24 , summarily disposing of the matter in litigation growing out of interferences. The summary treatment, however, was not the result of any conscious effort to avoid tackling the problem; the cases simply did not involve circumstances that would require a careful examination of the provision. For example, in Korman v. Shull, ${ }^{78}$ a district court case, the issue was the presence of "good cause" as then required under the federal rules for production of documents and things, ${ }^{79}$ an element the court found lacking. In dicta, the court did indicate that rules $26,30,34$, and 45 were applicable under section $24 .^{80}$ The statement, though, does not indicate how the district court would resolve the real questions of whether production is to be tested by evidentiary standards and whether pretrial dis-

76. See note 20 supra. There are three categories of inter partes proceedings before the Patent Office which involve rival claimants: opposition proceedings, which allow certain parties to oppose the registration of a mark; cancellation proceedings, which allow for contests of registrations by certain parties who contend there are grounds why the registration should not continue to be registered; and interference proceedings, where the parties litigate the issue of who is entitled to ownership and registration of the mark. While each proceeding is conducted like a patent interference at the trial stage, at least in the first two there is no "overlay" which would support the maintenance of a policy against broad pretrial discovery.

77. See generally $1 \mathrm{~J}$. McCARTHX, supra note 20 , 20.4 .

78. 184 F. Supp. 928, 125 U.S.P.Q. 280 (W.D. Mich. 1960).

79. Prior to the 1970 anendments to the federal rules, rule 34 required a court order on a showing of good cause as a condition precedeut to compelling production of documents and things from a party to a pending action.

80. Korman v. Shull, 184 F. Supp. 928, 931, 125 U.S.P.Q. 280, 282 (W.D. Mich. 1960). 
covery would be allowed. ${ }^{81}$ (Korman arose at the trial stage of the interference and the documents subpoenaed were sought as evidence which would have constituted part of the discoverer's case.)

In 1968, the Third Circuit became the first court to give section 24 extended discussion, holding in In re Natta that the measure mamfests "a clear congressional intent to make available to parties to patent interferences the broad discovery provisions of the Federal Rules of Civil Procedure."82 Although Natta involved a rule 34 motion after the jumior parties had presented their cases, ${ }^{83}$ and thus did not require pretrial discovery, the court ordered production even though the evidence sought may not have been admissible in the proceedings before the Patent Office. ${ }^{84}$

81. The Frilette majority was convinced that it had to limit applicability of the rules under section 24 solely to rule 45 . Since the court was maintaining that the statute was intended only to achieve a "continuity of authority," and because the statute preceding section 24 provided only for the issuance of subpoenas in compelling discovery, see note 24 supra, then present practice could permit parties to proceed only pursuant to rule 45 , which replaced the earlier subpoena statute. See notes 23-24 supra. The problein in such reasoning is that, whether one contends that only rule 45 is incorporated or that rules $26,30,34$, and 45 are all incorporated, the court must still ultimately contend that section 24 gives the district courts authority to einploy the rules only to obtain information as tested under evidentiary standards and not discovery standards. Essentially the desired evidence must be shown to be not only relevant but adnissible under the rules of evidence. To that end the Frilette court eliminates that portion of rule 45 which establishes that evidence sought need only be shown to be relevant, i.e., rule 45(d)(1). "We hold that 35 U.S.C. $\$ 24$. . . refers to the matters encompassed by FED. R. Crv. P. 45(a), (b), (c), (d) (2), (e), and (f)." 508 F.2d at 212, 184 U.S.P.Q. at 271. Seizing on rule 45 to the exclusion of the other "Federal Rules of Civil Procedure relating to the attendance of witnesses and to the production of documents and things," however, unnecessarily goes against the literal language of the statute. It does no harm to the theory behind Frilette's interpretation of section 24 to read it broadly in the sense of providing means other than rule 45 for coinpelling the production of evidence that would meet pre-section 24 standards. It would be the ultimate in formalistic procednre to deny, under a motion filed pursuant to another rule, that which would be allowed had the party entitled his motion as one pursuant to rule 45 .

This is not to say, however, that expanding the Frilette analysis in this manner would have any practical impact on the imterference. Specifically, rules 26 and 30 are of no import since the former merely sets out the scope of civil discovery and the latter, providing for depositions upon oral examination, depends for its efficacy on the rule 45 subpoena. As for rule 34, providing for the production of documents and things from parties, ancillary judicial discovery is unnecessary since the Commissioner of Patents, pursuant to Rule 259,37 C.F.R. $\$ 1.259$, has the power to compel testimony or evidence by the threat of disınissing the application. See Sheehan v. Doyle, Civil No. 74-1318 at 7 (1st Cir., Marcli 31, 1975).

82. 388 F.2d 215, 217, 156 U.S.P.Q. 289, 290 (3d Cir. 1968).

83. Id.

84. Id. at 219,156 U.S.P.Q. at 292 . The senior party was seeking production of documents to prove its case by rebutting attempts by the junior parties to establish an earlier date. Id. at 217, 156 U.S.P.Q. at 290. 
The cases following the Natta decision differ markedly from those that had preceded it. Accepting and expanding upon Natta, the courts have explicitly stated that section 24 should be read literally to apply broad discovery at all stages of the interference. In Babcock \& Wilcox Co. v. Combustion Engineering, Inc., ${ }^{85}$ a district court stated in dicta that "the broad mandate of the statute manifests an explicit congressional intent to allow both parties to a patent interference to apply for discovery at any time during the contested proceeding." ${ }^{866}$ The earliest cases actually sustaining pretrial discovery are Taub $v$. Rausser ${ }^{87}$ and Judd v. Englehard. ${ }^{88}$ Taub allowed a party to take depositions relating to a pending motion for dissolution of the interference, ${ }^{80}$ while Judd ordered discovery even though the Patent Office was still considering motions filed in the proceeding. ${ }^{90}$ Neither court discussed the scope of section 24 , nor offered authority for its action.

It was at this point, sir years after its inandate in Natta, that the Third Circuit reversed its position, holding in Frilette v. Kimberlin ${ }^{91}$ that the earlier decision gave an erroneously broad imterpretation to the statutory language. ${ }^{92}$ The case involved two inotions, one by a semor party for subpoenas duces tecum with respect to a preliminary motion to amend an original application, ${ }^{93}$ and the other by a junior party for discovery pursuant to Patent Rule 287(c) while the senior party was still filing preliminary docunients. ${ }^{94}$

85. 314 F. Supp. 235, 159 U.S.P.Q. 762 (D. Conn.), aff'd mem., 430 F.2d 1177 (2d Cir. 1968).

86. Id. at 237,159 U.S.P.Q. at 763 (emphasis added).

The impact of such language is reduced, however, by the fact that the court was responding to the contention that in all cases prior to Babcock the junior party had completed its case-in-chief and, therefore, discovery was permitted only for rebuttal purposes. The argument procceded that the court should not allow discovery of the senior party's case prior to that stage because allowing the junior party discovery any earlier would frustrate the order of precedence which the Patent Office desired to utilize. Thus, although the court's response indicates that it would allow broad "at-trial" discovery, it does not necessarily show that it would also allow pretrial discovery.

87. 159 U.S.P.Q. 220 (D.N.J. 1968).

88. 159 U.S.P.Q. 571 (E.D. Wis. 1968).

89. 159 U.S.P.Q. at 220. Significantly, as expected, the Cominissioner of Patents on petition refused to permit use of the pretrial depositions ordered in Taub in connection with the Rule 231 motion decision. In re Decision dated Aug. 12, 1968, 160 U.S.P.Q. 154 (1968). A better case could hardly be made for the view that evidence sought need not be admissible as evidence in the Patent Office proceeding in order to be discoverable.

90. 159 U.S.P.Q. at 571.

91. 508 F.2d 205, 184 U.S.P.Q. 266 (3d Cir. 1974), cert. denied, 43 U.S.L.W. 3614 (U.S. May 20, 1975).

92. 508 F.2d at 207, 184 U.S.P.Q. at 266.

93. Id. at 207, 184 U.S.P.Q. at 266.

94. Id. at 208, 184 U.S.P.Q. at 267. 
The Frilette court reasoned that Congress had meant only to maintain the continuity of authority granted to the courts under section 7 of the 1922 Patent Act, ${ }^{95}$ the predecessor of section $24 .{ }^{96}$ Apparently, this meant that there was to be no pretrial discovery, because discovery under the prior practice hinged on the admissibility of the evidence, and any evidence procured prior to trial did not constitute part of the record and was thus not admissible. ${ }^{97}$ Similarly, the scope of "at-trial" discovery was to be limited by standards of admissibility as under prior practice. ${ }^{98}$ The Court of Appeals felt compelled to "bite the bullet"99 and overrule its prior decision in light of the "negative repercussions"100 which ensued froin Natta, viewing these repercussions as justification for a reappraisal of the congressional history of the statute. ${ }^{101}$

It was not long before another circuit followed the path laid out by Frilette. The First Circuit, in Sheehan v. Doyle, ${ }^{102}$ passing on the matter for the first time, adopted the "arguments and analysis"103 of Frilette, dismissing contrary authority. Viewing section 24 in conjunction with section 23 , which confers general authority upon the Commissioner of Patents to promulgate discovery rules, ${ }^{104}$ the court decided that it had been Congress's intention that any discovery ${ }^{105}$ before the Patent Office proceed pursuant to the Commissioner's rules alone. The First Circuit therefore concluded that section 24 was designed only to give "teeth, through the court's subpoena powers, to authority conferred upon the Commissioner ...., and to provide a means of compelling testimony and evidence admissible as part of the record in the interference in addition to materials properly subject to

95. Act of Feb. 18, 1922, ch. 58, § 7, 42 Stat. 391.

96. See note 81 supra.

97. See note 67 supra.

98. See note 81 supra.

99. 508 F.2d at 207, 184 U.S.P.Q. at 266.

100. See notes $112-25$ infra and accompanying text.

101. "Judge Seitz's [dissenting] opinion in Natta reviews in detail the history of section 24. . . . It is because the majority believes that Judge Seitz correctly analyzed the statute that we now overrule Natta. The undesirable results of the Natta doctrine supply a background for reconsideration, not the reason for rejection of that case." 508 F.2d at 212 n.15, 184 U.S.P.Q. at 270 n.14a.

102. Civil No. 74-1318 (1st Cir., March 31, 1975). In Sheehan, one party to the interference, pursuant to rule 34 , had sought the production of documents from his adversary on the theory that section 24 contemplated such ancillary judicial discovery in the district courts.

103. Id. at 6.

104. Pursuant to the authority granted by 35 U.S.C. $\S 23$ (1970), Patent Office Rule 287, 37 C.F.R. $\$ 1.287$ (1974) was enacted.

105. See note 25 supra. 
Patent Office discovery. ${ }^{106}$

The complete turnaround of the Third Circuit and the recent decision of the First Circuit illustrate the inconclusive nature of the decisions dealing with the scope of discovery under section 24. While those circuits now hold that the statute sustains the district court's authority to compel discovery as it was prior to the adoption of the federal rules, decisions in other circuits ${ }^{107}$ supply authority for a literal reading of section $24 . .^{108}$

\section{The Effect of Broad Discovery in Interferences}

As the Frilette court acknowledged, the federal courts are necessarily bound by the jurisdiction Congress confers upon them. ${ }^{109}$ Thus, the undesirable results produced by the Natta decision can only supply a background for reconsidering the meaning of section 24, not the reason for rejecting the prior interpretation. ${ }^{110}$ Nevertheless, an examination of the problems associated with broad discovery, as the Third Circuit viewed them, helps in understanding why that court labored to find an artificial construction of the statute and why future courts might follow its lead, as indeed the First Circuit has already done.

The Frilette court was clearly concerned with the tension between the structure of the interference and the policy foundations of

106. Civil No. 74-1318 at 6. It is the failure to distinguish these two separate purposes under the Frilette-Sheehan irterpretation that causes both courts to conclude erroneously that under section 24 's mandate the courts can act only pursuant to the subpoena power. While it is true that as to the former purpose, the enforcement of Patent Office discovery orders, a subpoena pursuant to rule 45 is alone appropriate, there is nothing wrong with a party's proceeding pursuant to other discovery rules as long as the test for compulsion is not relevancy but admissibility under the established rules of evidence. Thus Sheehan's flat assertion that "section 24 does not confer jurisdiction upon the district court, acting on its own, to grant Rule 34 discovery . . . ., id. at 4, is unnecessarily restrictive. See note 81 supra.

107. See Babcock \& Wilcox Co. v. Combustion Eng'r, Inc., 430 F.2d 1177 (2d Cir.), aff'g mem., 314 F. Supp. 235 (D. Conn. 1968); Natta v. Zletz, 405 F.2d 99 (7th Cir. 1968), cert. denied, 395 U.S. 909 (1969); Natta v. Hogan, 392 F.2d 686 (10th Cir. 1968); Taub v. Rausser, 159 U.S.P.Q. 220 (D.N.J. 1968); Judd v. Englehard, 159 U.S.P.Q. 591 (E.D. Wis. 1968).

108. One particularly disturbing consequence of the conflicting interpretations of section 24 is that parties to the same interference proceeding iray not be treated equally under the law. It depends on the fortuity of location whether evidence is discoverable at all and if so at what point. For instance, in the Frilette case, one party located in the Second Circuit is now subject to discovery, but is barred from conducting discovery against the other party because of that party's presence in the Third Circuit. Petitioner's Brief for Certiorari at 3, 15-16, Frilette v. Kimberlin, 508 F.2d 205 (3d Cir. 1974).

109. 508 F.2d 205, 211, 184 U.S.P.Q. 266, 270 (3d Cir. 1974), cert. denied, 43 U.S.L.W. 3614 (U.S. May 20, 1975).

110. Id. at 212 n.15, 184 U.S.P.Q. 270 n.14a. 
the federal rules. Specifically, the court dealt with the Patent Office procedure requiring the junior party to compile his evidence first, ${ }^{11 i}$ in order to preserve the advantage accorded the senior party. Maintaining that the wisdom of the policy is irrelevant, the Third Circuit found harmful the exercise of ancillary jurisdiction by the district court to defeat a policy of the agency responsible for conducting and adjudicating the interference. ${ }^{112}$ The court did not discuss the other

111. See note 13 supra and accompanying text.

112. Id. at 210,184 U.S.P.Q. at 269.

It is important to note that other courts-even those which accept Natta-have acknowledged the problem precipitated by allowing discovery when it would run counter to Patent Office policy. Some have maintamed that the scope of discovery should and can be restricted under those circumstances. See, e.g., Babcock \& Wilcox Co. v. Foster Wheeler Corp., 415 F.2d 777, 779, 163 U.S.P.Q. 140, 141 (3d Cir. 1969) (concurring opinion); Morris v. Hillyer, 132 U.S.P.Q. 668 (D. Conn. 1961). This position is indefensible since courts are bound by the jurisdiction Congress confers upon them: "[The judiciary have] no more right to decline the exercise of jurisdiction which is given, than to usurp that which is not given. The one or the other would be treason to the constitution." Cohens v. Virginia, 19 U.S. (6 Wheat.) 264, 404 (1821).

"[T] veniens], but never has such an exception to the general rule been used to effect a wholesale eradication of power conferred by a particular statute." Babcock \& Wilcox Co. v. Foster Wheeler Corp., 163 U.S.P.Q. 480, 483 (D.N.J. 1972). The court concluded, "[t]he district court may not defer to the Board [of Patent Interferences] by declining to exercise its jurisdiction under 35 U.S.C. $\$ 24 \ldots$. . Id. (footnote omitted).

Significantly, legislation recently attempting to amend section 24 substantiates the conclusion that the courts have been acting incorrectly by gearing discovery thereunder to complement the Patent Rules. In 1968, 1969, and 1971 the Senate proposed to revise section 24 to read: "[t]he provisions of the Federal Rules of Civil Procedure relating to the attendance of witnesses and the production of documents and things shall apply to contested cases in the Patent Office insofar as consistent with such regulations." S. 3892, 90th Cong., 2d Sess. $\$ 24$ (1968); S. 1246, 91st Cong., 1st Sess. $§ 24$ (1969); S. 643, 92d Cong., 1st Sess. $\$ 24$ (1971) (emphasis added).

Similarly, the three bills introduced during the last Congress to amend, inter alia, section 24 all provided some means of adapting discovery to better fit within the confines of an interference proceeding. S. 1321, H.R. 7111, 93d Cong., 1st Sess. $\$ 23(\mathrm{~b})$ (1) (1973), provided for broad discovery "as procedural necessities within the (Patent) Office permit . . .." S. 2504, H.R. 10795, 93d Cong., 1st Sess. $\$ 23(b)(1)$ (1973), provided for discovery as under the federal rules "with such different time limits as the Commissioner may by regulation prescribe." S. 2930, 93d Cong., 2d Sess. $§ 24$ (1974), H.R. 11868, 93d Cong., 1st Sess. \$ 24 (1973), would have made the federal discovery rules applicable only "insofar as consistent with Patent Office regulations . . . ." Clearly, no such amendment is called for unless the present wording mandates the application of the federal rules in ancillary proceedings regardless of consistency with the Patent Office's regulations. One could argue that Congress refused to enact the bills because the measures merely restated present law, but that hardly explains why the amendment was so persistently reintroduced. Rather, there are compelling reasons for refusing to enact such legislation. Principally, as one writer put it, such a statute "would make the Commissioner of Patents the supreme arbiter of the garnering of evidence for interferences. He would have power to deprive parties to adversary proceedings before the Patent Office of access to any means for compelling document production from an opponent." Sears, Discovery in Interferences, 53 J. PAT. OFF. Soc'y 693, 707 (1971) (footuote omitted). 
sources of conflict discussed above, such as the peculiar need for secrecy during the early stages of the proceeding ${ }^{113}$ and the potential administrative burden caused by frequent objections to requests for information which is discoverable under the federal rules but not admissible in an interference. ${ }^{114}$

Another source of concern for the court was the disruption of Patent Office timetables by court-ordered stays, ${ }^{115}$ and the concomitant burden placed on litigants and the traditional processes of judicial administration by the appealability ${ }^{110}$ of district court orders granting or denying discovery. In addition, the Frilette court made the related point that there is no centralized control over the discovery proceedings, since an independent action can be brought in each district in which there is discoverable evidence. ${ }^{117}$ Section 24 sanctions resort to a district court in any jurisdiction where the documents are kept, which led the Court of Appeals to believe that "the usual rules of confining control of the litigation to the principal forum became obscured and unworkable." 118 Thus, in the court's view, the broad statutory interpretation violated several "tenets of good judicial administration."110

A third factor considered by the Frilette court was the diminished need for expansive discovery in the form of ancillary proceedings, in light of the discovery now permitted as part of the interference

113. See notes 38-44 supra and accompanying text.

114. See notes 45-48 supra and accompanying text.

115. 508 F.2d at 209-10, 184 U.S.P.Q. at 268-69.

116. While an order compelling testimony or the production of documents is not ordinarily appealable, see Alexander v. United States, 201 U.S. 117 (1906), the rule is to the contrary in a special proceeding having as its ultimate purpose the production of evidence. Such proccedings are regarded as independeut actions, with the result that orders compelling or refusing to compel testimouy or documents and things are appealable as final orders. See, e.g., Sheehan v. Doyle, Civil No. 74-1318 (1st Cir., Mar. 31, 1975); In re Natta, 410 F.2d 187, 189 n.2 (3d Cir. 1969); Natta v. Hogan, 392 F.2d 686, 157 U.S.P.Q. 183, 185-86 (10th Cir. 1968); Natta v. Zletz, 379 F.2d 615, 153 U.S.P.Q. 768, 771 (7th Cir. 1967); Ochsner v. Millis, 383 F.2d 618, 155 U.S.P.Q. 195 (6th Cir. 1967). But see Korman v. Nobile, 135 U.S.P.Q. 338 (6th Cir. 1962); Tucker v. Peiler, 297 F. 570 (2d Cir.), cert. denied, 265 U.S. 587 (1924). These contrary holdings are carlier cases and of doubtful authority.

It should be noted, however, contrary to the Frilette court's assertion that such a procedural posture is "unique," 508 F.2d at 209, 184 U.S.P.Q. at 270 , that independent proceedings for discovery are not uncommon. Sec 9 J. MooRE, supra note 24, at If $157-59$.

117. 508 F.2d at 211,184 U.S.P.Q. at 269-70.

118. $I d$.

119. Id. Sheehan similarly inaintained that "the unfortunate effect [of a broad reading of section 24] is to generate self-coutained discovery proceedings out of joint with the administrative proceeding to which, ostensibly, they are linked." Civil No. 74-1318 at 6. 


\section{itself ${ }^{120}$ under Patent Rule $287^{121}$ and the availability of de novo review}

120. Rule 287 may have an impact on the discovery that the district courts will entertain in ancillary proceedings. It is true that the promulgation of a rule by an admmistrative agency subsequent to the enactment of a statute could not possibly alter the legislative intent eunbodied in the statute. It is also true that the language of section 24 is mandatory so that it is improper for the district courts to declime to exercise jurisdiction in an effort to better complement Patent Office policy. Yet, in light of Rule 287, the courts may now deny discovery where it is otherwise allowable on the ground that such is the proper role of ancillary discovery proceedings. Specifically, drawing from the doctrine of exhaustion of administrative remedies, the parties should be required to pursue an administrative remedy before going to court. See generally $3 \mathrm{~K}$. Davis, AdminISTRATIVE LAW TREATTSE $\S \S 20.01-10$ (1958). In the absence of contrary legislation, it is virtually the universal rule that a court will require exhaustion "when the administrative remedy is as likely as the judicial remedy to provide the wanted relief." $I d$. $\$$ 20.01, at 56-57. On the other extreme the qnestion of exhaustion is not even raised if the agency, as was the case prior to Rule 287, offered absolutely no means of obtaining adequate relief. Id. at 56. Now, when there is at least a possibility of cventual relief, the issue of exhaustion comes to the fore.

The problem is that the exhaustion doctrine is technically concerned only with the timing of judicial review of administrative action, id. at 57 , which is not the case at hand. The analogy nevertheless is clear. In the instant circumstance, where either the federal agency or the district court can grant the discovering party material which he seeks, the same fundamental principles that sustain the exhaustion doctrine support the proposition that the specialized agency should have an opportunity to deal with the matter prior to the courts. Those principles are: "1) that questions should be decided by those most competent to do so, and 2) that questions should be decided in an orderly way." Comment, Exhaustion of State Administrative Remedies in Section 1983 Cases, 41 U. CHr. L. REv. 537, 538 n.9 (1974).

There are still areas of discovery totally precluded by Rule 287 even under the broad discretionary discovery of 287 (c), namely discovery prior to the close of the motions period and discovery from nonparties. But for those things covered by the nondiscretionary or discretionary portions of the rule, unless the party can show irreparable injury a strong case can be made for denial of ancillary discovery until the discovery mechanisms of Rule 287 have been invoked. As the Board rules on motions pursuant to Rule 287(c) and the parties begin to learn what to expect, however, the exhaustion doctrine may have less relevance. There is ample authority supporting the proposition that the administrative remedy need not be exhausted if previous decisions of a board make resort to it futile. See $3 \mathrm{~K}$. DAvis, supra $\$ 20.07$, at 99-100. The recent Sheehan decision holds that in all circumstances "use of federal courts as alternative forums of first resort to compel discovery rather than as forums acting strictly in aid of the primary proceeding" would be precluded. Civil No. 74-1318 at 6 . That holding, going much further than the actual case required, should be carefully distinguished, however. There, the court did not proceed on the basis of exhaustion of administrative remedies, but rather on its finding that section 24 did not confer jurisdiction upon the district court to act in any other capacity. See notes 102-06 supra and accompanying text.

On the other end of the spectrum is the situation where a district court might refuse to compel discovery sought after the commencement of the trial period, when the discovering party has passed up an opportunity to proceed under Rule 287 (c), on the ground that discovery is being sought too late. In Babcock \& Wilcox Co. v. Foster Wheeler Corp., 173 U.S.P.Q. 480, 483 (D. N.J. 1972), a district court denied discovery of otherwise discoverable material, reasoning from the principle that courts will compel parties to pursue their remedies with diligence. See 4A J. MOORE, supra note 24, Tा 34-43.

121. 37 C.F.R. $\$ 1.287$ (1974). 
in the district courts under section 146.122 Although "not as liberal"123 as the federal rules, Rule 287 requires the surrender of documents and things which each party intends to rely on, along with a hist of witnesses to be deposed. ${ }^{124}$ Under section 146 , new evidence inay be introduced in a district court proceeding, which is considered a civil action in equity rather than a direct appeal, and is thus triable on the merits. Discovery even at this late stage, then, may be adequate. ${ }^{125}$

These policy considerations are fairly persuasive. Indeed, they lead one to question seriously the wisdorn of the apparent congressional grafting of a broad discovery scheme onto the peculiar structure of the patent interference. ${ }^{120}$ Still, the language of section 24 stands squarely in the way of any judicial effort to accommodate these convincing factors.

\section{CoNCLUSION}

It seens very difficult to contend that section 24 does not incorporate into patent interference proceedings the broad scope of the federal discovery rules. To argue that the legislative history of the measure demands a contrary result appears an exercise in futility.

122. 35 U.S.C. \& $146(1970)$.

123. Frilette v. Kimberlin, 508 F.2d 205, 211, 184 U.S.P.Q. 266, 270 (3d Cir. 1974), cert. denied, 43 U.S.L.W. 3614 (U.S. May 20, 1975).

124. Patent Rule 287(a), 37 C.F.R. \& 1.287 (1974). Thus discovery as of right relates to matters upon which an opponent will rely; it does not require production of evidence which would build an affirmative case for the discoverer. The rule requires the junior party to furnish the senior party the information after the close of the period set by the Board of Interferences for the consideration of motions. The senior party need not provide his materials to the junior party until the latter has completed taking his testimony-in-chief. Rule 287(d)(1) stipulates that noncompliance with Rule 287(a) will bar a party from being able to rely on any document or thing not produced, with the exception that this can be avoided by motion and a showing of good cause for failure to comply with the Rule. Rule 287 (c) adds that the Board of Patent Interferences may grant further discovery between the parties during the preparation for testimony or thereafter to the full extent allowed under the Federal Rules of Civil Procedure upon a showiug of good cause.

125. Such an analysis cuts two ways, however. Every final decision awarding priority may also be appealed on the Patent Office record to the Court of Customs and Patent Appeals, 35 U.S.C. $\$ 141$ (1970), a route that will be taken only by a defeated party who is reasonably satisfied with the record. To lessen the burden on the district courts it would appear to be wise, therefore, to have the same scope of discovery in the interference as would be available under de novo review. It should be noted, though, that the advantage of the additional evidence allowed to be taken pursuant to a section 146 appeal is counterbalanced in part by the presumption of administrative correctness in such a proceeding. See, e.g., In re Natta, 264 F. Supp. 734, 738, 153 U.S.P.Q. 11, 15 (D. Del. 1967), aff'd 388 F.2d 215 (3d Cir. 1968).

126. It led the First Circuit to conclude that the broad reading section 24 had traditionally been given went "beyond what Congress could reasonably have had in mind." Sheehan v. Doyle, Civil No. 74-1.31.8 at 6 (emphasis added). 
Nevertheless, there are strong policy reasons for desiring that section 24 be limited in scope.

The conclusion, however, seems inescapable that the Frilette court, along with any court which adopts its analysis, is reaching its lolding for policy reasons alone, and thus usurping the legislative function. ${ }^{127}$ The court in Sheehan, in fact, nade no effort to allay fears that legislation was precisely what it was doing. ${ }^{128}$

It is true that Congress apparently failed to give consideration to the peculiarities of the patent interference proceeding when it formulated section 24 . The broad discovery appropriate for litigation in the district courts is ill-suited for patent interference litigation as it is now structured. Although discovery plays an important and beneficial role in the patent interference, the virtually untrammeled discovery inandated by the statutory language hampers the procedure favored by the Patent Office in seeking just resolutions of first inventor questions and needlessly burdens the decision-making process.

Courts liave acknowledged these difficulties, and some liave refused to compel section 24 discovery where to do so would offend a policy of the Patent Office. ${ }^{129}$ They liave at least suggested a deference to the judgment of the Board of Patent Interferences on the propriety of discovery in individual cases. ${ }^{130}$ The First and Third Circuits have moved more boldly, adopting a strained interpretation of the statute to apply in all cases. These decisions can be viewed as merely an extension of the same type of judicial response-avoidance of the negative impact of legislation that judges regard as poorly conceived. Yet instead of selectively denying discovery where Congress has ordered it, they liave ignored the express mandate altogether. One can only liope that the structure of the patent interference will soon be changed, or that section 24 will be amended. ${ }^{131}$ If easing the tension between the statute and Patent Office policy is not impetus enough, surely ending the type of judicial legislation engendered by the conflict is.

127. It is significant that the promulgation of Rule 287 now makes it possible for district courts to deny ancillary discovery for policy reasons. Recognition and application of this approach could mean that fewer courts will follow the lead of Frilette. See note 120 supra.

128. Indeed, even the dissenters in Frilette did not dispute this fact, basing their objection instead on the proposition that a federal court cannot abrogate its responsibility to assume jurisdiction under section 24. 508 F.2d at 223, 184 U.S.P.Q. at 278-79.

129. See note 112 supra.

130. See note 120 supra.

131. Three patent reform bills introduced during the last Congress were not reported out of committee. See S. 1321, H.R. 7111, 93d Cong., 1st Sess. (1973); S. 2504, H.R. 10,795, 93d Cong., 1st Sess. (1973); S. 2930, 93d Cong., 2d Sess. (1974), H.R. 11,868, 93d Cong., 1st Sess. (1973). 